\title{
Removal of methylene blue using activated carbon prepared from date stones activated with $\mathrm{NaOH}$
}

\author{
Gherbia A. ${ }^{1,2^{*}}$, Chergui A. ${ }^{1}$, Yeddou A.R. ${ }^{1}$, Selatnia Ammar S. ${ }^{1}$ and Boubekeur N. ${ }^{1}$ \\ ${ }^{1}$ Laboratoire d'Etude et de Développement des Techniques de Traitement et d'Epuration des Eaux et de Gestion Environnementale \\ LEDTEGE, Ecole Normale Supérieure, KOUBA BP 92, Algiers, Algeria \\ 2Université de Laghouat, Département des Sciences et Techniques, Faculté de Technologie, Laghouat, Algeria \\ Received: 10/10/2018, Accepted: 21/05/2019, Available online: 24/05/2019 \\ *to whom all correspondence should be addressed: e-mail: \\ https://doi.org/10.30955/gnj.002913
}

\begin{abstract}
Synthetic dyes have a hurtful effect on human health and the environment. In this work, activated carbon was produced from date stones for use in elimination of methylene blue charged in aqueous solutions. Before that, the adsorbent was characterized by BET method, SEM, $\mathrm{X}$-ray and TGA. The results of the adsorption kinetics are describe better with the pseudo-second order model $\left(R^{2}=0.998\right)$. Frendlich adsorption isotherm model describe better the experimental data than the Langmuir model. The capacity for methylene blue removal was found to be $163.67 \mathrm{mg} / \mathrm{g}$. Batch experiments studies show that the activated carbon produced as of date stones can be used effectively in the treatment of cationic dyes in aqueous solutions.
\end{abstract}

Keywords: Adsorption, kinetic, isotherm, activated carbon, methylene blue.

\section{Introduction}

The existence of organic micro pollutants and inorganic substances in the waters has much interesting attention of the international scientific community, favoring new research, oriented to class and to measure the toxicological potentialities of an extremely great number of organic chemicals and inorganic substances. Industrial discharges are the main sources of water contamination, may cause serious environmental consequences for ecosystems to all taxonomic groups (algae, bacteria, fish, birds, mammals) (Couture et al.,1989; Gupta and Saini, 2005; Ian et al., 2006; Saha et al., 2012; Schreurs et al., 2004).

Synthetic dyes are used in many industrial sectors such as dyeing of textile, paper, leather, food, cosmetics industries and pharmaceutical products (Bartonova et al., 2017; Robinson et al., 2001; Umpuch and Sakaew, 2013; Yagub et al., 2015). Textile industries cause pollution of water which are harmful to the environment, such as certain carcinogenic azo dyes, they require physicochemical techniques to degrade them (Aksu et al., 2005).

A various techniques (Physico-chemical and biological) have been developed and tested for water filled with dyes. These techniques include adsorption (Hamdaoui et al., 2006), coagulation-flocculation (Verma et al., 2012), ion exchange (Karcher et al., 2002), membrane filtration (Avlonitis et al., 2008), Fenton reagent (El Haddad et al., 2014), photo-catalysis of hydrogen peroxide (Aleboyeh and Aleboyeh, 2015), peroxonation (Pekey, 2016), photolysis of hydrogen peroxide and ozonation (Alaton et al., 2002); biological treatment (Chellaiah et al., 2018).

Activated carbon is widely used for the treatment of wastewater due to its internal surface which makes them ideal for the removal of soluble substances from water (Iqbal and Ashiq, 2007).

The agricultural solid waste as an abundant and cheap material widely used as raw adsorbent or converted into activated carbon by a physical activation process such as pistachio shells (Attia et al., 2003), almond shells (Maaloul et al., 2017), rattan sawdust (Hameed et al., 2007), cotton stalk (Deng et al., 2009), orange peel (Foo and Hameed, 2012), hazelnut shell (Şayan, 2006), oil-palm shell (Lua and Jia, 2009), coffee residue (Boonamnuayvitaya et al., 2004), mangosteen peel (Ahmad and Alrozi, 2010), eucalyptus wood (Mane and Babu, 2011), powdered peanut hull (Gong et al., 2005), bagasse (Valix et al., 2004), sunflower stalks (Šæiban et al., 2008), Sugarcane (Ibrahim et al., 2006), mango seed kernel (Vasanth and Kumaran, 2005), coconut coir dust (Macedo et al., 2006), groundnut shells (Kannan and Sundaram, 2001), oil-palm (Cheng et al., 2017), Apricot stones (Kobya et al., 2005), banana pith (Kadirvelu et al., 2003), coir pith (Kavitha and Namasivayam, 2007), Peach stones (Amina et al., 2008). Glucose, cellulose and hazelnut shells (Çaglar et al., 2018). Algeria is one of leading producers of dates with about $14 \%$ of world production, according to the statistics of FAO (2013), Algeria ranks the $4^{\text {th }}$ in terms of date production, after Saudi Arabia, Egypt and Iran. 
Deglet Nour, Ghars and Degla Beida are the main varieties of dates produced in Algeria. The agri-food industries generate an important amount of date stones that are usually considered as waste. This work aims to produce activated carbon as of date stones as a waste agriculture for use in the removal of dye from water, particularly for the removal of textile industry effluents.

\section{Materials and methods}

\subsection{Preparation of adsorbent}

Deglat Beida stones as an agricultural solid waste were obtained from Biskra, Algeria, the sample was washed repeatedly with tap water to remove soluble impurities, dried under a period of 24 hours at $60{ }^{\circ} \mathrm{C}$, followed by mechanical grind to obtain fine particles of diverse sizes. The particles were washed in distilled water to eliminate soluble organic matter and floating matter in the water, filtered using a Wattman membrane $\mathrm{N}^{\circ} 4$ then dried at $60{ }^{\circ} \mathrm{C}$, impregnated in solution of $\mathrm{NaOH}$ its concentration $0.5 \mathrm{M}$ for $4 \mathrm{~h}$. The sample was then washed in distilled water until the sample was neutralized, filtrated and dried in the oven at $60^{\circ} \mathrm{C}$ for $24 \mathrm{~h}$. The sample was heated in an electric oven with heating ramps $5{ }^{\circ} \mathrm{C}$ per min until $600{ }^{\circ} \mathrm{C}$ was maintained for one hour. The activated carbon (CNDB) obtained by this treatment were washed with distilled water, filtered and dried at $100{ }^{\circ} \mathrm{C}$ for 2 hours and then sieved using a sieve RETCH Model AS 200 to obtain a particle size between 315-500 $\mu \mathrm{m}$.

\subsection{Preparation of $M B$ solution}

A stock solution containing $500 \mathrm{mg} / \mathrm{L}$ of $\mathrm{MB}$ was prepared by dissolving required mass of methylene blue $\left(\mathrm{C}_{16} \mathrm{H}_{18} \mathrm{~N}_{3} \mathrm{SCl}\right.$, 98.5\% purity, Fluka) in the distilled water. Adsorption tests solutions were used by dilution stock solution. $\mathrm{pH}$ of the solutions was adjusted by $0.1 \mathrm{M}$ hydrochloric acid $37 \%$ purity, Chemistry-Plus or by addition of a $0.1 \mathrm{M}$ solution of sodium hydroxide $98 \%$ purity, Fluka Chemika.

\subsection{Characterization of the activated carbon}

Nitrogen adsorption measurements were performed using QuadraSorb SI MP Station at $77 \mathrm{~K}$ to determine the Surface area of ACDB. A MEB FEG JEOL 6700F scanning electron microscope (SEM) was used to observe the surface morphologies of ACDB. Philips $X^{\prime}$ Pert X-ray diffraction was used to identify the nature of the crystalline and amorphous phases present in ACDB. Thermo gravimetric analysis (TGA) of NDB sample was carried out by TGA/SDTA $851^{\mathrm{e}}$ Mettler-Toledo. Thermal analyzer, on weight of $7.6416 \mathrm{mg}$ at a heating range from 25 to $950{ }^{\circ} \mathrm{C}$ under $10{ }^{\circ} \mathrm{C} / \mathrm{min}$ and $40 \mathrm{ml} / \mathrm{min}$, heating rate and an air flow rate respectively.

\subsection{Batch adsorption studies}

Adsorption tests of the cationic dye methylene blue $M B$ solution on activated carbon ACDB were carried out in batch system by mixing $0.08 \mathrm{~g}$ of ACDB with $50 \mathrm{ml}$ containing $500 \mathrm{mg} / \mathrm{L}$ of $\mathrm{MB}$. For the measurement of $\mathrm{pH}$ solution a Hanna pH-meter model: 211 , the solution was used and adjusted by $0.1 \mathrm{M}$ of sodium hydroxide or hydrochloric acid. The contact time parameter effect was studied at different time interval from 5 to $360 \mathrm{~min}$ at $\mathrm{pH}$ value of 6 and $25^{\circ} \mathrm{C}$ and initial concentration of $500 \mathrm{mg} / \mathrm{L}$ of $\mathrm{MB}$. The $\mathrm{pH}$ parameter effect on the quantity of cationic dye $\mathrm{MB}$ adsorbed was studied in range 2 to 10 at $25{ }^{\circ} \mathrm{C}$. The effect of adsorbent dose on the adsorption of $\mathrm{MB}$ was studied for different masses from 0.01 to $0.1 \mathrm{~g}$ at $\mathrm{pH} 6$ and a temperature of $25{ }^{\circ} \mathrm{C}$. Adsorption isotherm experiments were performed into different initial concentrations of $\mathrm{MB}$ between 50 and $500 \mathrm{mg} / \mathrm{L}$ at $\mathrm{pH} 6$ and $25^{\circ} \mathrm{C}$, were shaken for $24 \mathrm{~h}$ to reach equilibrium.

The concentration of $\mathrm{MB}$ in the solution was determined by UV-Visible Optizen $1412 \mathrm{~V}$ Spectrophotometer at wavelength of $664 \mathrm{~nm}$.

The quantity of cationic dye MB adsorbed at equilibrium concentration was calculated by the following expression (Rong and Qi, 2010):

$q_{e}=\frac{\left(C_{0}-C_{e}\right)}{m} \times V$

Where $C_{e}$ and $C_{0}(\mathrm{mg} / \mathrm{L})$ are the residual concentration of $\mathrm{MB}$ at equilibrium and the primarily concentration of adsorbate $M B$, respectively. $V(L)$ is the solution volume, and $\mathrm{m}(\mathrm{g})$ is the mass of ACDB used.

\section{Results and discussion}

\subsection{Characterization of adsorbent}

From the Figure 1, the SEM observation shows the presence of very remarkable cavities due to the chemical treatment with $\mathrm{NaOH}$ and the pyrolysis at $600{ }^{\circ} \mathrm{C}$ which improves the porosity of the adsorbent (formed cavities) of ACDB. Figure 2 shows the $\mathrm{N}_{2}$ adsorption-desorption isotherm of activated carbon ACDB, the plot demonstrates a typical isotherm type I (Storck et al., 1998; Chen and Zeng, 2003) reveal microporous adsorbent according to the classification of IUPAC. The specific surface area of ACDB was found to be $S_{B E T}=248.38 \mathrm{~m}^{2} / \mathrm{g}$ measured by the method of BET at $\left(p / p_{0}\right)$ range [0.05-0.3].

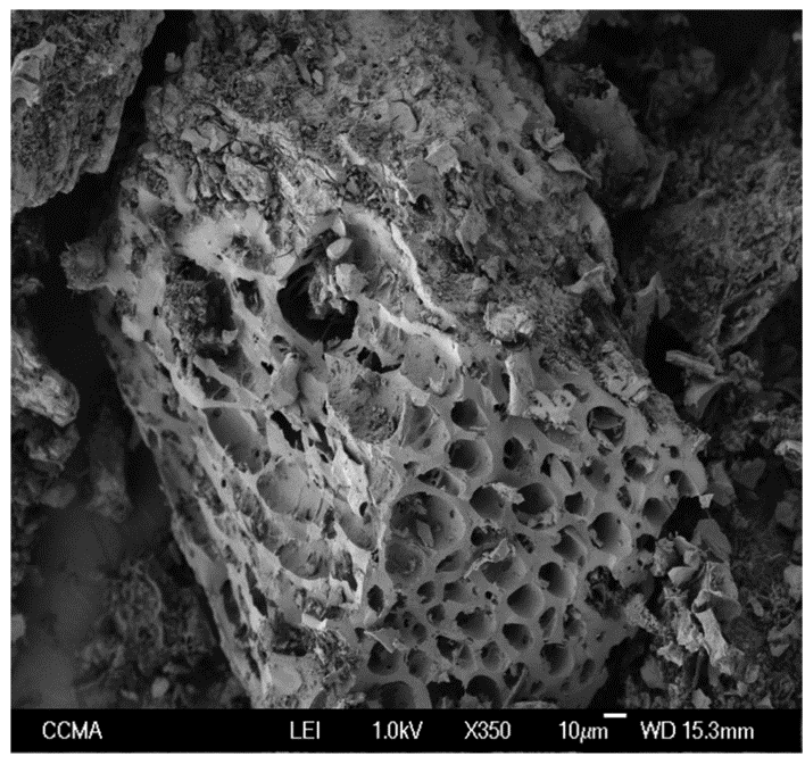

Figure 1. SEM image of $A C D B$ 
The X-ray diffraction results of the samples treated with sodium hydroxide and activated carbon before and after the adsorption of methylene blue NDB, NDB-MB, ACDB and $A C D B-M B$ respectively, are shown in Figure 3 , the diffraction spectrum of NDB and NDB-BM show the same spectrum and exhibit the same diffraction peaks at $2 \theta^{\circ}=16.7$ and $2 \theta^{\circ}=21$ which are attributed respectively to the cellulose (Hui et al., 2015), peak intensity of the two diffraction peaks have no change after $M B$ adsorption, which indicates that the adsorption is produced in the amorphous region, the disappearance of these peaks for the activated carbon before and after the adsorption of methylene blue ACDB and ACDB-MB respectively, was attributed to the degradation of cellulose, the spectrum before or after the adsorption on activated carbon has no change, which also reveals that the adsorption is produced in the amorphous region. Thermogravimetric analysis for the raw adsorbent treated with sodium hydroxide (NDB) is presented in Figure 4. The TGA/DTG curves show that CNDB thermal decomposition has three stages. Dehydration which ended at $150{ }^{\circ} \mathrm{C}$, with a maximum mass loss of $5.9(\%)$. Then, the combustion of volatile matter and combustion phase until the peak temperature of $382{ }^{\circ} \mathrm{C}$, with a very brutal mass loss of $58.57(\%)$, followed by, the last stage corresponds to the combustion of char until $550{ }^{\circ} \mathrm{C}$, with a mass loss of 27.48 (\%) (Ge et al., 2015; Munir et al., 2009).

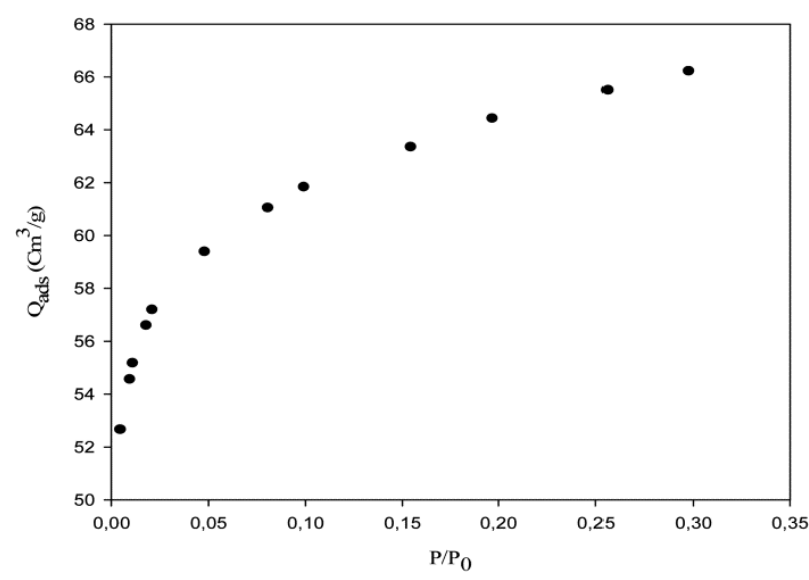

Figure 2. $\mathrm{N}_{2}$ adsorption-desorption isotherms of $A C D B$ at $77 \mathrm{~K}$

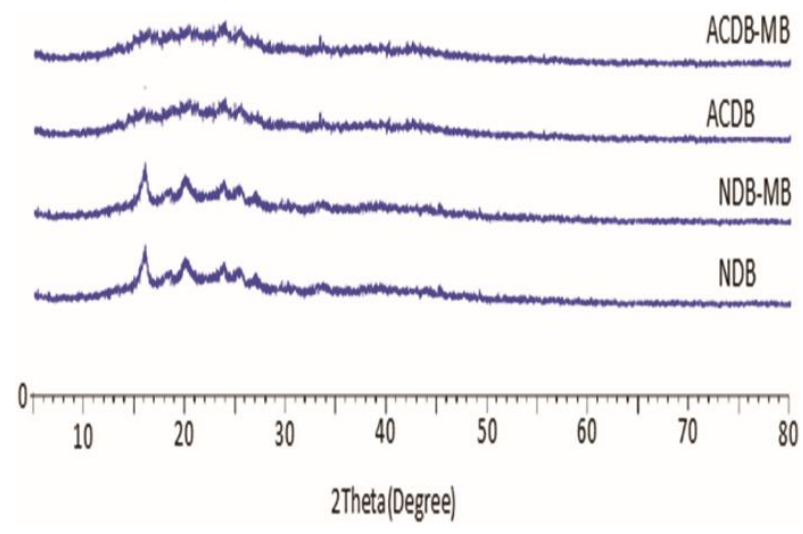

Figure 3. X-ray diffraction of $A C D B$

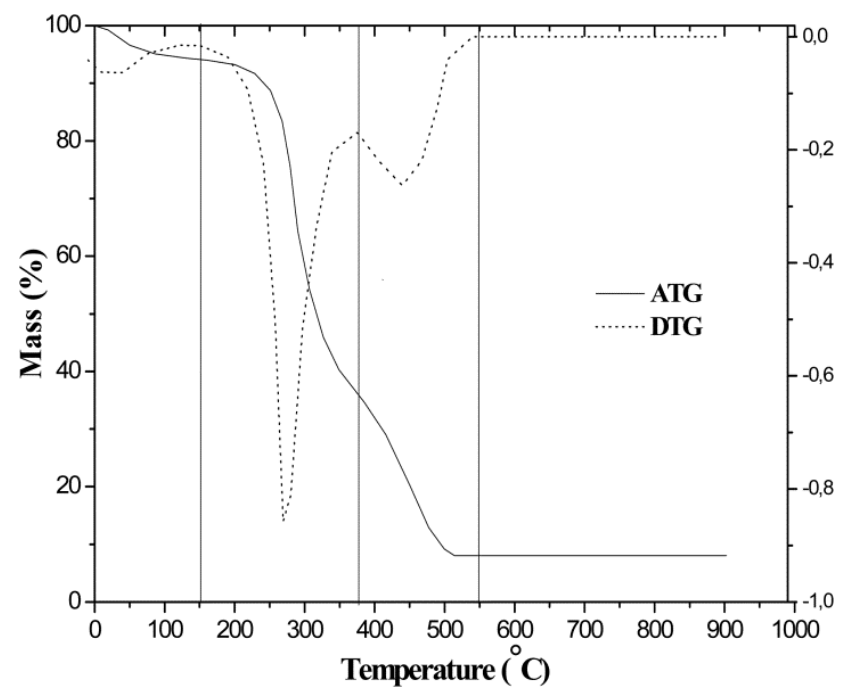

Figure 4. TGA/DTG curves of $A C D B$

\subsection{Effect of $\mathrm{pH}$ on adsorption of $M B$}

The initial $\mathrm{pH}$ value is a very important parameter to consider for controlling the adsorption removal process in aqueous solution, it can change, speciation of molecules surface, charge of the adsorbent and degree of ionization of the adsorbate (Aksu et al., 2005; Miretzky and Munoz, 2011; Yao et al., 2010). Figure 5, shows the effect of initial $\mathrm{pH}$ on the adsorption of methylene blue on ACDB. Increasing of initial $\mathrm{pH}$ values from 2 to 10 enhances the adsorption capacity of MB from 89.07 to $207.09 \mathrm{mg} / \mathrm{g}$. At higher initial $\mathrm{pH}$ values, the surface of the adsorbent CNDB adopts the negatives charges sites which favorites the adsorption of BM cations by electrostatic attraction while at lower initial $\mathrm{pH}$ values the surface of the CADB adopts the positive charge which causes a decrease in $B M$ adsorbed due to the electrostatic repulsion, similar results were obtained by other studies on $\mathrm{MB}$ adsorption by activated carbon (AL-Aoh et al., 2013; Karagöz et al., 2008; Postai et al., 2016).

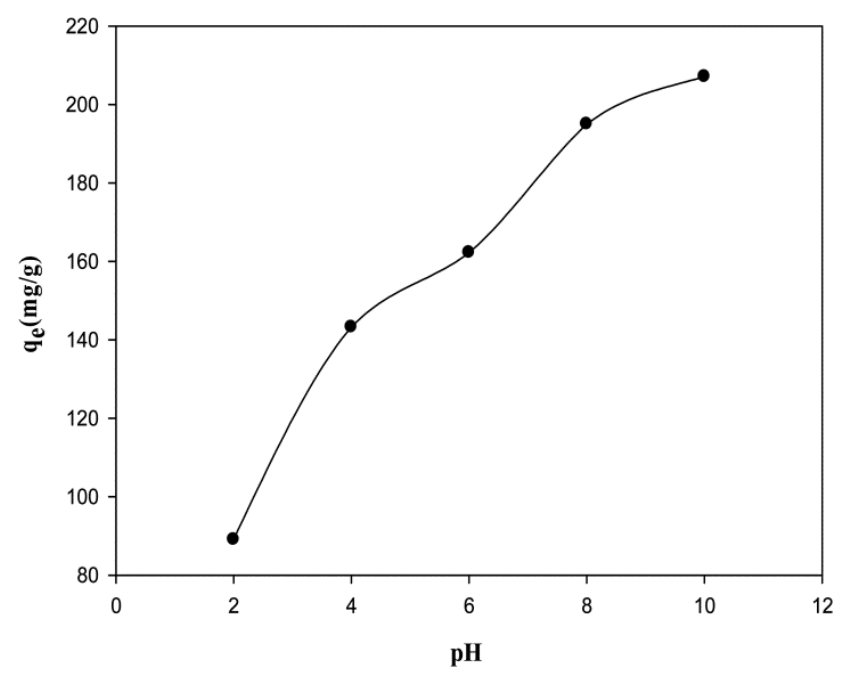

Figure 5. Effect of initial $\mathrm{pH}$ on the adsorption equilibrium of $M B$ using ACDB 


\subsection{Effect of adsorbent dose}

The effect of the adsorbent dose on the adsorption capacity and the adsorption efficiency of MB were studied on ACDB adsorbents. Figure 6 illustrates that the adsorption efficiency augmented with the increase of the adsorbent amount, while the amount adsorbed decreases with increasing mass. This may probably due to the augmented surface area and number of active sites available for the fixation of methylene blue. This is similar to the studies reported by (Jain et al., 2015; Mehta et al., 2016; Uddin et al., 2009).

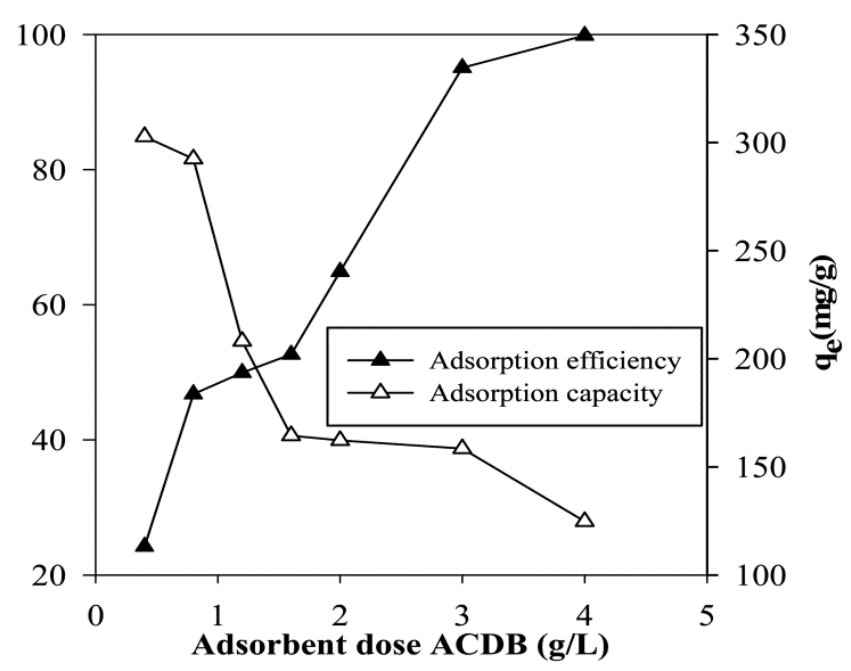

Figure 6. Effect of adsorbent dose on the adsorption of $M B$ by ACDB

\subsection{Adsorption kinetics}

In order to determine the kinetic model for the removal of $M B$ on ACDB, two models have been applied such as pseudo-first order model and pseudo-second order model, were represented respectively by the following equations (Uddin et al., 2009; Sarici-Özdemir and Önal, 2014).

$\ln \left(q_{e}-q_{t}\right)=\ln q_{e}-K_{1} t$

$\frac{t}{q_{t}}=\frac{1}{K_{2} q_{e}^{2}}+\frac{1}{q_{e}} t$

Where, $\mathrm{q}_{\mathrm{e}}$ and $\mathrm{q}_{\mathrm{t}}(\mathrm{mg} / \mathrm{g})$ are the quantity of $\mathrm{MB}$ adsorbed at equilibrium and adsorbed at instant $t$ ( $\mathrm{min}$ ), respectively, $k_{1}(1 / \mathrm{min})$ and $k_{2}(\mathrm{mg} / \mathrm{g} \mathrm{min})$ are the rate constants of both models.

Figure 7a and $b$ show the comparison between the kinetic models, pseudo-first order model and pseudo-second order model for the adsorption of $\mathrm{MB}$ on the ACDB. The values of kinetic parameter of both kinetic models are included in the Table 1 . The results appear that the model of pseudo-second order was the best for describing the kinetic of methylene blue compared to the other model pseudo-first order. The value of correlation coefficients $R^{2}$ was superior than 0.99 also the values of $\left(q_{e}\right.$, cal $)$ calculated from the model of pseudo-second order was approach to the experimental value $\left(q_{\exp }\right)$, indicating the applicability of this model to the adsorption of MB on ACDB.

Table 1. Kinetic parameters for $\mathrm{MB}(500 \mathrm{mg} / \mathrm{L})$ adsorption on ACDB

\begin{tabular}{ccccccc}
\hline & \multicolumn{2}{c}{ Pseudo-first order } & \multicolumn{3}{c}{ Pseudo-second order } \\
\hline $\mathrm{q}_{\exp }(\mathrm{mg} / \mathrm{g})$ & $\mathrm{q}_{\mathrm{e}, \text { cal }}(\mathbf{m g} / \mathbf{g})$ & $\mathbf{k}_{\mathbf{1}}(\mathbf{1} / \mathbf{m i n})$ & $\mathbf{R}^{\mathbf{2}}$ & $\mathbf{q}_{\mathrm{e}, \text { cal }}(\mathbf{m g} / \mathbf{g})$ & $\mathbf{k}_{\mathbf{2}}(\mathbf{m g} / \mathbf{g ~ m i n})$ & $\mathbf{R}^{\mathbf{2}}$ \\
\hline 163.67 & 100.4 & 0.749 & 0.984 & 169.4 & 0.00047 & 0.998 \\
\hline
\end{tabular}
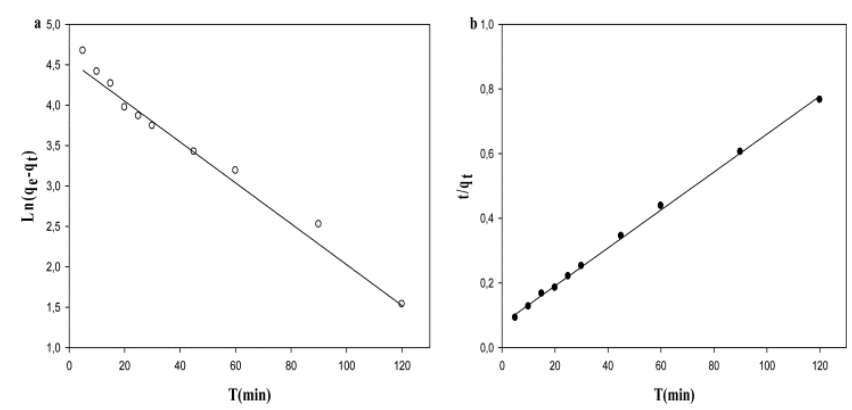

Figure 7. Pseudo-first order (a), pseudo-second order (b) for the adsorption of $\mathrm{MB}$ on $\mathrm{ACDB}$

\subsection{Adsorption isotherms}

In order to comprehend the adsorption mechanism for different initial concentrations, and also to identify the isotherm represents the adsorption of $M B$ on $A C D B$
(Figure 8). Two theoretical models were tested on the experimental results obtained by application of both Freundlich and Langmuir models. The isotherm equation linear form of models Freundlich and Langmuir are written respectively by the following equations (Yao et al., 2010):

$\ln q_{e}=\ln K_{F}+\frac{1}{n} \ln C_{e}$

$\frac{C_{e}}{q_{e}}=\frac{1}{q_{m} b}+\frac{1}{q_{m}} C_{e}$

Where $C_{e}$ represents the equilibrium concentration $(\mathrm{mg} / \mathrm{L}), \mathrm{q}_{\mathrm{m}}$ is the maximum quantity of $\mathrm{MB}$ adsorbed (mg/g) and $\mathrm{K}_{\mathrm{L}}$ is the thermodynamic constant of equilibrium $(1 / \mathrm{mg}), K_{F}$ is the Freundlich constant $(L / m g)$, and $(1 / n)$ the heterogeneity factor. 


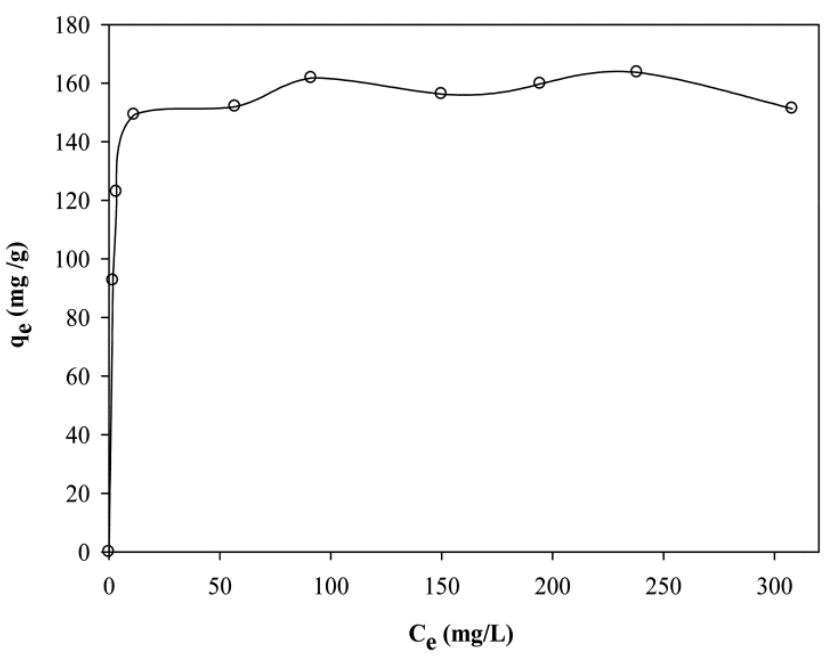

Figure 8. Adsorption isotherm of $M B$ on $A C D B$

The essential characteristics of the Langmuir isotherm can be described by a separation factor RL (Bulut et al., 2008):

$R_{L}=\frac{1}{1+K_{L} C_{0}}$

The value of $R_{L}$ indicates the type of isotherm, favorable if $\left(0<R_{L}<1\right)$, unfavorable if $\left(R_{L}>1\right)$, linear $\left(R_{L}=1\right)$ and irreversible if $\left(R_{L}=0\right)$ (Doğan et al., 2008).

Table 2. Isotherm parameters for the adsorption of BM from aqueous solution by ACDB

\begin{tabular}{|c|c|c|c|c|c|c|}
\hline \multicolumn{4}{|c|}{ Langmuir constants } & \multicolumn{3}{|c|}{ Freundlich constants } \\
\hline $\begin{array}{c}q_{\max } \\
(\mathrm{mg} / \mathrm{g})\end{array}$ & $\begin{array}{c}\mathrm{K}_{\mathrm{L}} \\
(\mathrm{I} / \mathrm{mg})\end{array}$ & $\mathbf{R}_{\mathbf{L}}$ & $\mathbf{R}^{2}$ & $\begin{array}{c}\mathrm{K}_{\mathrm{F}} \\
(\mathrm{L} / \mathrm{mg})\end{array}$ & $1 / n$ & $\mathbf{R}^{2}$ \\
\hline 43.10 & 0.007 & 0.222 & 0.477 & 120.9 & 0.056 & 0.794 \\
\hline
\end{tabular}

Figure 9a and $b$ show the comparison of the linear forms of Langmuir and Freundlich isotherms for the adsorption of methylene blue ACDB. According to the Table 2, the maximum fixing capacity of methylene blue on ACDB is $163.67 \mathrm{mg} / \mathrm{g}$, Figure 9b shows a better applicability of the Freundlich model which has the highest correlation factor compared to the Langmuir model, indicating the possibility of multilayer adsorption, it is also noted that the slope values $(1 / n)$ are less than 1 , which represents that the adsorption is favorable with an L-type isotherm (Shavandi et al., 2012). The adsorption capacity values of other works from the literature are illustrated in the Table 3.
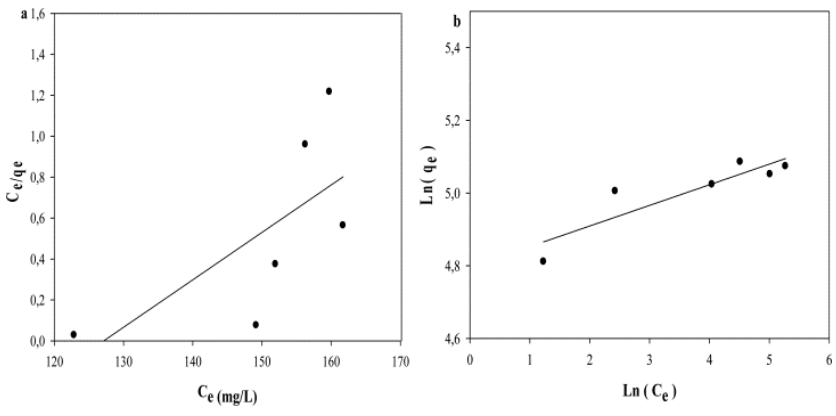

Figure 9. Linearizations according to Langmuir (a) and Freundlich (b)
Table 3. Comparison of adsorption capacities of various adsorbents for $\mathrm{MB}$

\begin{tabular}{ccc}
\hline Adsorbents & $\mathbf{q}_{\exp }$ ( $\left.\mathbf{m g} / \mathbf{g}\right)$ & References \\
\hline Acrylic fibrous & 20.6 & Naeem et al., 2016 \\
\hline Banana pith & 04.6 & Kadirvelu et al., 2003 \\
\hline Sepiolite & 57.3 & Alkan et al., 2008 \\
\hline Iron impregnated AC & 30.61 & Shah et al., 2015 \\
\hline Rattan sawdust & 294.1 & Hameed et al., 2007 \\
\hline Coir pith & 05.8 & Kavitha and \\
& & Namasivayam, 2004 \\
\hline Pistachio shells & 129.0 & Attia et al., 2003 \\
\hline Attapulgite/bentonite & 168.6 & Liu et al., 2014 \\
\hline Mango seed kernel & 142.8 & Vasanth et al., 2005 \\
\hline Titanate nanotubes & 133.3 & Xiong et al., 2010 \\
\hline Coconut coir dust & 15.2 & Macedo et al., 2006 \\
\hline Groundnut shell & 164.9 & $\begin{array}{c}\text { Kannan and } \\
\text { Sundaram, 2001 }\end{array}$ \\
\hline Grinding palygorskite & 111.7 & Zhang et al., 2015 \\
\hline Coconut leaves & 149.3 & Jawad et al., 2016 \\
\hline AC Degla Beida stones & 163.6 & This work \\
\hline
\end{tabular}

\section{Conclusion}

This study estimated the adsorption performance of methylene blue $\mathrm{MB}$ dye from aqueous solution by activated carbon prepared from date stones ACDB and confirmed the possibility of valorizing the date stones as agricultural solid waste. The influence of the initial $\mathrm{pH}$ and adsorbent dose were studied, the results show that the adsorption capacity enhance with increase in the initial $\mathrm{pH}$ value of the aqueous solution and the adsorption efficiency increased with the increase of the adsorbent dose, maximum methylene blue removal was 163.67 $\mathrm{mg} / \mathrm{g}$. Experimental data was best approved with the kinetic model of pseudo second-order and best described by Freundlich model. This paper concludes that the activated carbon prepared from date stones ACDB can be used as low-cost adsorbent for the removal of methylene blue dye from aqueous solution.

\section{References}

Ahmad M.A. and Alrozi R. (2010), Optimization of preparation conditions for mangos teen peel-based activated carbons for the removal of remazol brilliant blue $\mathrm{R}$ using response surface methodology. Chemical Engineering Journal, 165, 883-890.

Aksu Z. (2005), Application of biosorption for the removal of organic pollutants: A review. Process Biochemistry, 40, 997-1026.

Aleboyeh A., Moussa Y. and Aleboyeh H. (2005), The effect of operational parameters on $\mathrm{UV} / \mathrm{H}_{2} \mathrm{O}_{2}$ decolourisation of Acid Blue 74. Dyes and Pigments, 66, 129-134.

Alaton I.A., Balcioglu I.A. and Bahnemann D.W. (2002), Advanced oxidation of a reactive dye bath effluent: comparison of $\mathrm{O}_{3}$, $\mathrm{H}_{2} \mathrm{O}_{2}$ /UV-C and $\mathrm{TiO}_{2}$ /UV-A processes. Water Resources, 36, 1143-1154.

AL-Aoh H.A., Yahya R., Maah M.J. and Bin Abas M.R. (2013), Adsorption of methylene blue on activated carbon fiber prepared from coconut husk: isotherm, kinetics and thermodynamics studies. Desalination and Water Treatment, 52, 1-13. 
Alkan M., Doğan M., Turhan Y., Demirbaş O. and Turan P. (2008), Adsorption kinetics and mechanism of maxilon blue $5 \mathrm{G}$ dye on sepiolite from aqueous solutions. Chemical Engineering Journal, 139, 213-223.

Amina A.A., Badie S.G. and Nady A.F. (2008), Removal of methylene blue by carbons derived from peach stones by $\mathrm{H}_{3} \mathrm{PO}_{4}$ activation: Batch and column studies. Dyes and Pigments, 76, 282-289.

Attia A.A., Girgis B.S. and Khedr S. (2003), Capacity of activated carbon derived from pistachio shells by $\mathrm{H}_{3} \mathrm{PO}_{4}$ in the removal of dyes and phenolics. Journal of Chemical Technology \& Biotechnology, 78, 611-619.

Avlonitis S.A., Poulios I., Sotiriou D., Pappas M. and Moutesidis K. (2008), Simulated cotton dye effluents treatment and reuse by nanofiltration. Desalination, 221, 259-267.

Bartonova L., Ruppenthalova L. and Ritz M. (2017), Adsorption of Naphthol Green B on unburned carbon: 2- and 3-parameter linear and non-linear equilibrium modeling. Chinese Journal of Chemical Engineering, 25, 37-44.

Boonamnuayvitaya V., Chaiya C., Tanthapanichakoon W. and Jarudilokkul S. (2004), Removal of heavy metals by adsorbent prepared from pyrolyzed coffee residues and clay. Separation and Purification Technology, 35, 11-22.

Bulut E., Ozacar M. and Sengil I.A. (2008), Equilibrium and kinetic data and process design for adsorption of Congo Red onto bentonite. Journal of Hazardous Materials, 154, 613-622.

Çaglar E., Donar Y.O., Sinag A., Birogul I., Bilge S., Aydincak K. and Pliekhov O. (2018), Adsorption of anionic and cationic dyes on biochars., produced by hydrothermal carbonization of waste biomass: effect of surface functionalization and ionic strength. Turkish Journal of Chemistry, 42, 86-99.

Chen S. and Zeng H. (2003), Improvement of the reduction capacity of activated carbon fiber. Carbon, 41, 1265-1271.

Cheng W., Liu G., Wang X. and Han L. (2017), Adsorption Removal of Glycidyl Esters from Palm Oil and Oil Model Solution by Using Acid-Washed Oil Palm Wood-Based Activated Carbon: Kinetic and Mechanism Study. Journal of Agricultural and Food Chemistry, 65, 9753-9762.

Chellaiah E.R. (2018), Cadmium (heavy metals) bioremediation by Pseudomonas aeruginosa: a minireview. Applied Water Science, 8, 154.

Couture P., Blaise C., Cluis D. and Bastien C. (1989), Zirconium toxicity assessment using bacteria, algae and fish assays. Water, Air, \& Soil Pollution, 47, 87-100.

Deng H., Yang L., Tao G. and Dai J. (2009), Preparation and characterization of activated carbon from cotton stalk by microwave assisted chemical activation-application in methylene blue adsorption from aqueous solution. Journal of Hazardous Materials, 166, 1514-1521.

Doğan M., Abak H. and Alkan M. (2008), Biosorption of Methylene Blue from Aqueous Solutions by Hazelnut Shells: Equilibrium., Parameters and Isotherms. Water, Air, \& Soil Pollution, 192, 141-153.

El Haddad M., Regti A., Laamari M.R., Mamouni R. and Saffaj N. (2014), Use of Fenton reagent as advanced oxidative process for removing textile dyes from aqueous solutions. Journal of Materials and Environmental Science, 5, 667-674.

Foo K.Y. and Hameed B.H. (2012), Preparation, Characterization and evaluation of adsorptive properties of orange peel based activated carbon via microwave induce $\mathrm{K}_{2} \mathrm{CO}_{3}$ activation. Bioresource Technology, 104, 679-689.

Ge Y.Q., Zhang W.Q., Xue G. and Zhao J.C. (2015), Carbonization of Chlorinated Organic Residual Liquid for Energy Source
Generation. Journal of Materials Science and Chemical Engineering, 3, 95-103.

Gong R., Ding Y., Li M., Yang C., Liu H. and Sun Y. (2005), Utilization of powdered peanut hull as biosorbent for removal of anionic dyes from aqueous solution. Dyes and Pigments, 64, 187-192.

Gupta V., Ali I. and Saini V. (2004), Removal of rhodamine B., fast green., and methylene blue from wastewater using red mud., an aluminum industry waste. Industrial \& Engineering Chemistry Research, 43, 1740-1747.

Hamdaoui O. (2006), Batch study of liquid-phase adsorption of methylene blue using cedar sawdust and crushed brick. Journal of Hazardous Materials, 135, 264-273.

Hameed B.H., Ahmad A.L. and Latiff K.N.A. (2007), Adsorption of basic dye methylene blue. onto activated carbon prepared from rattan sawdust. Dyes and Pigments, 75, 143-149.

Hui H., Jubin Z., Kangli L. and Yayun T. (2015), Characterization of Acidosasa edulis shoot shell and its biosorption of copper ions from aqueous solution. Journal of Environmental Chemical Engineering, 3, 357-364.

Ian J.F., Deborah J.P. and Vernon G.T. (2006), A review of lead poisoning from ammunition sources in terrestrial birds. Biological Conservation, 131, 421-432.

Ibrahim S.C., Hanafiah M.K.A.M. and Yahya M.Z.A. (2006), Removal of cadmium from aqueous solution by adsorption on sugarcane bagasse. American-Eurasian Journal of Agricultural \& Environmental Sciences, 1, 179-184.

Iqbal M.J. and Ashiq M.N. (2007), Adsorption of dyes from aqueous solutions on activated charcoal. Journal of Hazardous Materials, 139, 57-66.

Jain M., Garg V.K., Garg U.K., Kadirvelu K. and Sillanpää M. (2015), Cadmium Removal from Wastewater using Carbonaceous Adsorbents Prepared from Sunflower Waste. International Journal of Environmental Research, 9, 10791088.

Jawad A.H., Rashid A.R., Ishak M.A.M. and Wilson L.D. (2016), Adsorption of methylene blue onto activated carbon developed from biomass waste by $\mathrm{H}_{2} \mathrm{SO}_{4}$ activation: kinetic equilibrium and thermodynamic studies. Desalination and Water Treatment, 57, 25194-25206.

Kadirvelu K., Kavipriya M., Karthika C., Radhika M., Vennilamani N. and Pattabhi S. (2003), Utilization of various agricultural wastes for activated carbon preparation and application for the removal of dyes and metal ions from aqueous solutions. Bioresource Technology, 87, 129-132.

Kannan N. and Sundaram M.M. (2001), Kinetics and mechanism of removal of methylene blue by adsorption on various carbons-a comparative study. Dyes and Pigments, 51, 25-40.

Karagöz S., Tay T., Ucar S. and Erdem M. (2008), Activated carbons from waste biomass by sulfuric acid activation and their use on methylene blue adsorption. Bioresource Technology, 99, 6214-6222.

Karcher S., Kornmüller A. and Jekel M. (2002), Anion exchange resins for removal of reactive dyes from textile wastewaters. Water Research 36, 4717-4724.

Kavitha D. and Namasivayam C. (2007), Experimental and kinetic studies on methylene blue adsorption by coir pith carbon. Bioresource Technology, 98, 14-21.

Kobya M., Demirbas E., Senturk E. and Ince M. (2005), Adsorption of heavy metal ions from aqueous solutions by 
activated carbon prepared from apricot stone. Bioresource Technology, 96, 1518-1521.

Kumar R.V., Ghoshal A.K. and Pugazhenthi G. (2015), Fabrication of zirconia composite membrane by insitu hydrothermal technique and its application in separation of methyl orange. Ecotoxicology and Environmental Safety, 121, 73-79.

Liu Y., Kang Y.R., Mu B. and Wang A.Q. (2014), Attapulgite/bentonite interactions for methylene blue adsorption characteristics from aqueous solution. Chemical Engineering, 237, 403-410.

Lua A.C. and Jia Q.P. (2009), Adsorption of phenol by oil-palmshell activated. Chemical Engineering Journal, 150, 455-461.

Maaloul N., Oulego P., Rendueles M., Ghorbal A. and Díaz M. (2017), Novel biosorbents from almond shells: Characterization and adsorption properties modeling for $\mathrm{Cu}(\mathrm{II})$ ions from aqueous solutions. Journal of Environmental Chemical Engineering, 5, 2944-2954.

Macedo J.S., Júnior N.B. and Almeida L.E. (2006), Kinetic and calorimetric study of the adsorption of dyes on mesoporous activated carbon prepared from coconut coir dust. Journal of Colloid and Interface Science, 298, 515-522.

Mane V.S. and Vijay Babu P.V. (2013), Kinetic and equilibrium studies on the removal of Congo red from aqueous solution using Eucalyptus wood, Eucalyptus globulus saw dust. Journal of the Taiwan Institute of Chemical Engineers, 44, 81-88.

Mehta D., Mondal P. and George S. (2016), Utilization of marble waste powder as a novel adsorbent for removal of fluoride ions from aqueous solution. Journal of Environmental Chemical Engineering, 4, 932-942.

Miretzky P. and Munoz C. (2011), Enhanced metal removal from aqueous solution by Fenton activated macrophyte biomass. Desalination, 271, 20-28.

Munir S., Daood S.S., Nimmo W., Cunliffe A.M. and Gibbs B.M. (2009), Thermal analysis and devolatilization kinetics of cotton stalk, sugar cane bagasse, and shea meal under nitrogen and air atmospheres. Bioresource Technology, 100, 1413-1418

Naeem S., Baheti V., Militky J., Wiener J., Behera P. and Ashraf A. (2016), Sorption properties of iron impregnated activated carbon web for removal of methylene blue from aqueous media. Fibers and Polymers, 17, 1245-1255.

Pekey H. (2016), Peroxidation treatment of dye manufacturing wastewater in the presence of ultraviolet light and ferrous ions. Desalination and Water Treatment, 57, 9845-9858.

Popuri S.R., Vijaya Y., Boddu V.M. and Abburi K. (2009), Adsorptive removal of copper and nickel ions from water using chitosan coated PVC beads. Bioresource Technology, 100, 194-199.

Postai D.L., Demarchi C.A., Zanatta F., Melo D.C.C. and Rodrigues C.A. (2016) Adsorption of rhodamine $b$ and methylene blue dyes using waste of seeds of aleurites moluccana, a low cost adsorbent. Alexandria Engineering Journal, 55, 1713-1723.

Robinson T., McMullan G., Marchant R. and Nigam P. (2001), Remediation of dyes in textile effluent: a critical review on current treatment technologies with a proposed alternative. Bioresource Technology, 77, 247-255.

Rong L.Z. and Qi Z.S. (2010), Adsorption of copper and nickel on Na-bentonite. Process Safety and Environmental Protection, 88, 62-66.
Saha P., Das Mishra R. and Husk R. (2012), Adsorption of safranin onto chemically modified rice husk in a upward flow packed bed reactor: artificial neural network modeling. Biotechnology Advances, 44, 7579-7583.

Šæiban M., Klašnja M. and Škrbiæ B. (2008), Adsorption of copper ions from water by modified agricultural by-products. Desalination, 229, 170-180.

Sarici-Özdemir Ç. and Önal Y. (2014), Error Anlaysis Studies of Dye Adsorption onto Activated Carbon from Aqueous Solutions. Particulate Science and Technology, 32, 20-27.

Şayan E. (2006), Ultrasound-assisted preparation of activated carbon from alkaline impregnated hazelnut shell: an optimization study on removal of $\mathrm{Cu}^{2+}$ from aqueous solution. Chemical Engineering Journal, 115, 213-218.

Shah I., Adnan R., Ngah W. and Norita M. (2015), Iron impregnated activated carbon as an efficient adsorbent for the removal of methylene blue: Regeneration and kinetics studies. PLoS One, 10, e0122603.

Shavandi M.A., Haddadian Z., Ismail M.H.S., Abdullah N. and Abidin Z.Z. (2012), Removal of Residual Oils from Palm Oil Mill Effluent by Adsorption on Natural Zeolite. Water, Air, \& Soil Pollution, 223, 4017-4027.

Schreurs R.H.M.M., Legler J., Artola-Garicano E., Sinnige T.L. and Lanser W. (2004), In Vitro and in Vivo Antiestrogenic Effects of Polycyclic Musks in Zebrafish. Environmental Science \& Technology, 38, 997-1002.

Storck S., Bretinger H. and Maier W.F. (1998), Characterization of micro- and mesoporeous solids by physisorption methods and pore-size analysis. Applied Catalysis A: General, 174, 137-146.

Tepe O. (2018), Adsorption of Remazol Brillant Green 6B (RBG $6 B)$ on chitin: process optimization using response surface methodology, Global NEST Journal, 20, 257-268.

Vasanth K. and Kumaran A. (2005), Removal of methylene blue by mango seed kernel powder. Biochemical Engineering Journal, 27, 83-93.

Valix M., Cheung W.H. and McKay G. (2004), Preparation of activated carbon using low temperature carbonization and physical activation of high ash raw bagasse for acid dye adsorption. Chemosphere, 56, 493-501.

Verma A.K., Dash R.R. and Bhunia P. (2012), A Review on Chemical Coagulation/Flocculation Technologies for Removal of Colour from Textile Wastewaters. Journal of Environmental Management, 93, 154-168.

Uddin Md T., Islam, Md A., Mahmud S. and Rukanuzzaman M. (2009), Adsorptive removal of methylene blue by tea waste. Journal of Hazardous Materials, 164, 53-60.

Yagub M.T., Sen T.K., Afroze S. and Ang H.M. (2015), Fixed-bed dynamic column adsorption study of methylene blue, MB. onto pine cone. Desalination and Water Treatment, 55, 1026-1039.

Yao Z.Y., Qi J.H. and Wang L.H. (2010), Equilibrium, kinetic and thermodynamic studies on the biosorption of $\mathrm{Cu}(\mathrm{II})$ onto chestnut shell. Journal of Hazardous Materials, 174, 137-143.

Xiong L., Yang Y., Mai J., Sun W., Zhang C., Wei D., Chen Q. and $\mathrm{Ni}$ J. (2010), Adsorption behavior of methylene blue onto titanate nanotubes. Chemical Engineering Journal, 156, 313320.

Zhang Y., Wang W.B., Zhang J.P., Liu P. and Wang A.Q.A. (2015), comparative study about adsorption of natural palygorskite for methylene blue. Chemical Engineering Journal, 262, 390398. 